\title{
BMPR1B wt Allele
}

National Cancer Institute

\section{Source}

National Cancer Institute. BMPR1B wt Allele. NCI Thesaurus. Code C73560.

Human BMPR1B wild-type allele is located within 4q22-q24 and is approximately $397 \mathrm{~kb}$ in length. This allele, which encodes bone morphogenetic protein receptor type IB protein, plays a role in the regulation of signaling. Mutations in the gene are associated with both acromesomelic chondrodysplasia with genital anomalies and brachydactyly types A2 and C. 